\title{
Coffee seedling growthafter legume cultivation in soils with contrasting phosphorus contents ${ }^{1}$
}

\author{
Djalma Silva Pereira' ${ }^{1}$, Liovando Marciano da Costa $^{1}$ (D), Davi Lopes do Carmo ${ }^{1}$, \\ Ana Caroline Teixeira Rocha' ${ }^{1}$, Antônio Alves Pereira² ${ }^{\text {(D) }}$
}

\begin{abstract}
${ }^{1}$ Universidade Federal de Viçosa/UFV, Departamento de Solos, Viçosa, MG, Brasil ${ }^{2}$ Empresa de Pesquisa Agropecuária de Minas Gerais/EPAMIG, Viçosa, MG, Brasil

Contact authors: djalma.pereira7@gmail.com, liovandomc@yahoo.com.br, davigoldan@yahoo.com.br, anacaroline.rocha17@gmail.com, tonico.epamig@gmail.com Received in February 26, 2021 and approved in June 16, 2021
\end{abstract}

\begin{abstract}
Coffee seedling growth depends on soil phosphorus $(\mathrm{P})$ availability and may be influenced by from pre-cultivation with legumes. Efficient and sustainable ways to increase the bioavailability of $P$ through the recovery of $P$ adsorbed by the soil matrix should be sought. This study proposed to evaluate the growth and $P$-use efficiency of coffee seedlings cultivated in soils with different $P$ availability after cultivation with legumes. The experiment was carried out in a fully randomized design. Treatments were arranged in a factorial scheme $[(2 \times 4)+1]$ : two soil types, pre-cultivation with four legume species, and one control (without pre-cultivation). The studied soils comprised a Typical Acriferic Red Oxisol (LVwf) with low-P availability and a Typical Chernossolic Litholytic Entisol (RLm) with high-P availability. The legume species Crotalaria juncea, Cajanus cajan, Canavalia ensiformis, and Mucuna aterrima were previously cultivated for 45 days. Afterwards, coffee seedlings were transplanted to the pots, which were then grown for 120 days until evaluations. We assessed the following parameters: plant height $(\mathrm{H})$, stem diameter (SD), shoot dry matter (SDM), root dry matter (RDM), total dry matter (TDM), and shoot contents of macronutrients. Our results showed that coffee seedlings grew more when cultivated in the high-P availability soil, with increments of $13.05 \%$ in $\mathrm{H}, 4.86 \%$ in SD, $46.98 \%$ in SDM, $17.61 \%$ in RDM, and $41.80 \%$ in TDM.We also observed an increase of $28.09 \%$ in shoot P contents for coffee seedlings grown in RLm. Moreover, pre-cultivation with $C$. juncea provided the largest increases in coffee seedling growth compared to the control. When grown after $C$. ensiformis cultivation, coffee seedlings had the highest shoot contents of $\mathrm{P}, \mathrm{Ca}, \mathrm{Mg}$, and $\mathrm{S}$, which, compared to control, increased by $45 \%, 39 \%, 18 \%$, and $17 \%$, respectively.
\end{abstract}

Keywords: Canavalia ensiformis; Crotalaria juncea; Coffea arabica; phosphate fertilization; nutritional efficiency.

\section{INTRODUCTION}

As coffee has economic and social significance in Brazil, further research intended to increase phosphorus $(\mathrm{P})$ absorption efficiency and its influence on coffee growth is needed since it is related to productivity. Coffee seedlings require macro-and micronutrients for their full development (Vilela Junior et al., 2017). Among the macronutrients, $\mathrm{P}$ is one of the most significant since it increases root development and vigor (Santinato et al., 2014), which are indispensable to ensure plant growth, development, and productivity.

Highly weathered tropical soils have low-P availability to plants due to a high interaction between phosphates and soil solidphase components, adsorbing or precipitating P, thus making it unavailable to plants. The retention of $\mathrm{P}$ added to the soil occurs both by its precipitation in solution with ionic forms of iron (Fe), aluminum ( $\mathrm{Al})$, and calcium $(\mathrm{Ca})$, and by its adsorption by $\mathrm{Fe}$ and Al oxyhydroxides (Novais; Smith, 1999). In soils with low-P availability, applications of high $\mathrm{P}$ contents are customary to raise contents close to the critical level (Raij, 2011).

Some studies have evidenced the relationship between P supply via phosphate fertilizers and coffee seedling grow thin plant nursery (Tomaz et al., 2009; Lemos et al., 2015; Silva et al., 2019). There has been a growing concern about how long society will be able to rely on the supply of phosphate fertilizers, which are currently limited to phosphate rock deposits (Elser; Bennett, 2011). In this sense, strategies aimed at replacing phosphate fertilizers, and then prolonging the time of use of such mineral reserves, are needed. Hence, $\mathrm{P}$ cycling in native soils and its use by pre-cultivation (legumes) and successor (coffee) plants are relevant factors to be investigated and are thus the focus of our study.

Crop rotation with highly efficient species in extracting $\mathrm{P}$ from the soil is one of the methods to cycle this element by converting unavailable into more labile forms (Silva et al., 2011). This practice can increase $\mathrm{P}$ efficiency in agricultural production systems since succeeding crops may use mineralized $\mathrm{P}$ after previous crop shoot and root decomposition (Soltangheisi et al., 2018). Among the crops commonly used in rotation systems as cover and green manure, legumes stand out.

Legumes have been widely used in crop rotation and green manuring due to their higher nitrogen $(\mathrm{N})$ releases. This occurs due to the ability of legumes to associate with nitrogen-fixing bacteria, in addition to their high potential to mobilize and absorb nutrients, producing large amounts of phytomass (Amabile; Carvalho, 2006). Unlike what is seen for $N$, there are few studies relating $\mathrm{P}$ mineralization rates with biochemical traits of legumes (Casali et al., 2011). In this sense, the use of legumes in crop rotation or green manuring can also act as a complementary source of $\mathrm{N}$ and increase $\mathrm{P}$ use efficiency by plants.

${ }^{1}$ Part of the first author's PhD thesis. 
Unavailable $\mathrm{P}$ forms can be solubilized and made available to plants through the cultivation of some legumes, which has been considered an attractive strategy for the management of soils with high phosphate adsorption capacity (Mascarenhas; Wutke, 2014). According to Nziguheba and Bünemann (2005), the use of plants as green manure can increase $P$ availability in two circumstances: (a) during their growth when soil properties change and hence $\mathrm{P}$ is mobilized; or (b) during their decomposition when organic $\mathrm{P}$ is mineralized.

The inclusion of species with high $\mathrm{P}$ absorption efficiency in the crop rotation can contribute to the $\mathrm{P}$ nutrition of the subsequent crop, thus reducing the need for phosphate fertilizers. Coffee plants can benefit from precultivation with legumes to provide P. Based on the above considerations, the purpose of our study was to evaluate the growth of coffee seedlings and their P-use efficiency when grown in soils with different $\mathrm{P}$ availability and after cultivation with legumes.

\section{MATERIALS AND METHODS}

\subsection{Study location}

The experiment was conducted in a green house at the campus of the Federal University of Viçosa (UFV), in the city of Viçosa, Minas Gerais State (Brazil). It is located at the geographical coordinates of $\mathrm{X}=518969.59$ and $\mathrm{Y}=$ 4919485.31, and an altitude of $651 \mathrm{~m}$. According to Köppen's classification (1948), the local climate is warm-temperate, with rainy summers and cold, dry winters (Cwb). From 1968 to 2010 , average annual rainfallwas $1,268.2 \mathrm{~mm}$, relative humidity around $81 \%$, and average annual temperature 20 ${ }^{\circ} \mathrm{C}$, according to data obtained from a local weather station (Lorenzon; Dias; Leite, 2013).

\subsection{Soil characterization}

Soil samples (horizon A) were collected at the city of Lagoa Formosa (Minas Gerais, Brazil) and corresponded to two soil classes: Typical Acriferic Red Oxisol (in Portuguese: Latossolo Vermelho Acriférrico típico - LVwf) and Typical Chernossolic Litholytic Entisol (in Portuguese: Neossolo Litólico Chernossólico típico $-R L m)$. The sampled sites had no agricultural use. To collect the soil, mini-trenches were opened along low traffic roads, and the soils was collected at a depth of 0 to $0,3 \mathrm{~m}$. The geographic coordinates of the sampling sites are X: 353390.67; Y: 7926050.50 (soil LVwf); and X: 362621.72; Y: 7919872.49 (soil RLm). The soil samples were characterized physically and chemically, without using repetitions, following the methodologies described by Teixeira et al. (2017), the results of which are shown in Table 1.
Table 1: Physicochemical properties of the soils used in the study.

\begin{tabular}{|c|c|c|}
\hline \multirow{2}{*}{ Property } & \multicolumn{2}{|c|}{ Soil type } \\
\hline & LVwf & RLm \\
\hline Coarse sand $\left(\mathrm{kg} \mathrm{kg}^{-1}\right)$ & 0.085 & 0.073 \\
\hline Fine sand $\left(\mathrm{kg} \mathrm{kg}^{-1}\right)$ & 0.079 & 0.082 \\
\hline Silt $\left(\mathrm{kg} \mathrm{kg}^{-1}\right)$ & 0.232 & 0.360 \\
\hline Clay $\left(\mathrm{kg} \mathrm{kg}^{-1}\right)$ & 0.603 & 0.486 \\
\hline $\mathrm{Sd}\left(\mathrm{kg} \mathrm{m}^{-3}\right)$ & 1170.00 & 1220.00 \\
\hline $\operatorname{Pd}\left(\mathrm{kg} \mathrm{m}^{-3}\right)$ & 3080.00 & 2890.00 \\
\hline $\mathrm{pH} \mathrm{H} \mathrm{H}_{2} \mathrm{O}(1: 2.5)$ & 5.72 & 6.01 \\
\hline $\mathrm{Ca}^{2+}\left(\mathrm{cmol}_{\mathrm{c}} \mathrm{kg}^{-1}\right)$ & 0.46 & 15.08 \\
\hline $\mathrm{Mg}^{2+}\left(\mathrm{cmol}_{\mathrm{c}} \mathrm{kg}^{-1}\right)$ & 0.18 & 4.32 \\
\hline $\mathrm{K}^{+}\left(\mathrm{mg} \mathrm{dm}^{-3}\right)$ & 29.00 & 163.00 \\
\hline Available P Mehlich-1 $\left(\mathrm{kg} \mathrm{m}^{-3}\right)$ & 0.0017 & 0.768 \\
\hline Total P $\left(\mathrm{mg} \mathrm{dm}^{-3}\right)$ & 2969.25 & 7419.85 \\
\hline Remaining P (kg) & 0.0062 & 0.0133 \\
\hline $\mathrm{Al}^{3+}\left(\mathrm{cmol}_{\mathrm{c}} \mathrm{kg}^{-1}\right)$ & 0.00 & 0.00 \\
\hline $\mathrm{H}+\mathrm{Al}\left(\mathrm{cmol}_{\mathrm{c}} \mathrm{kg}^{-1}\right)$ & 5.90 & 8.30 \\
\hline $\mathrm{TB}\left(\mathrm{cmol}_{\mathrm{c}} \mathrm{kg}^{-1}\right)$ & 0.71 & 19.82 \\
\hline $\operatorname{CEC}\left(\mathrm{cmol}_{\mathrm{c}} \mathrm{kg}^{-1}\right)$ & 0.71 & 19.82 \\
\hline${ }_{\mathrm{e}} \mathrm{CEC}\left(\mathrm{cmol}_{\mathrm{c}} \mathrm{kg}^{-1}\right)$ & 6.61 & 28.12 \\
\hline$\% \mathrm{BS}$ & 10.70 & 70.50 \\
\hline $\mathrm{OM}\left(\operatorname{dag} \mathrm{kg}^{-1}\right)$ & 2.74 & 3.91 \\
\hline
\end{tabular}

LVwf: Typical Acriferic Red Oxisol; RLm: Typical Chernossolic Litholytic Entisol; Sd: soil density; Pd: particle density; TB: total bases; \%BS: base saturation; CEC: cation exchange capacity at $\mathrm{pH} 7 ;{ }_{e} \mathrm{CEC}$ : effective cation exchange capacity; OM: organic matter.

\subsection{Experimental design}

The experiment was carried out in a fully randomized design (FRD) with six replicates. Treatments were arranged in a factorial scheme $[(2 \times 4)+1]$ and defined as: two soil types, pre-cultivation with four legume species, and a control (without pre-cultivation) totaling 60 experimental plots.

\subsection{Coffee seedling cultivation}

The experimental plots consisted of rigid polyethylene pots, with a capacity of $3 \mathrm{dm}^{3}$ soil. First, the legume species Crotalaria juncea, Cajanus cajan, Canavalia ensiformis, and Mucuna aterrima were cultivated. The soils were fertilized (except for P) according to the recommendations of Novais et al. (1991). For both soils, the doses of nutrients consisted of $0.1,0.04,0.00081,0.00366,0.00015,0.004,0.00133$, and $0.00156 \mathrm{~kg} \mathrm{~m}^{-3}$ soil of $\mathrm{N}, \mathrm{S}, \mathrm{B}, \mathrm{Mn}, \mathrm{Mo}, \mathrm{Zn}, \mathrm{Cu}$, and $\mathrm{Fe}$, respectively, and the following sources were used: $\mathrm{NH}_{4} \mathrm{NO}_{3}$, $\mathrm{K}_{2} \mathrm{SO}_{4}, \mathrm{H}_{3} \mathrm{BO}_{3}, \mathrm{MnCl}_{2} \cdot 4 \mathrm{H}_{2} \mathrm{O}, \mathrm{NaMoO}_{4} \cdot 2 \mathrm{H}_{2} \mathrm{O}, \mathrm{ZnCl}_{2}, \mathrm{Cu} \mathrm{Cl}$, and $\mathrm{FeCl}_{3} \cdot 6 \mathrm{H}_{2} \mathrm{O}$, respectively. Besides, in the $\mathrm{LVwf}$ soil, $0.3 \mathrm{~kg}$ 
$\mathrm{m}^{-3}$ of $\mathrm{K}$ was applied, using $\mathrm{KCl}$ as the source, as well as $0.00204 \mathrm{~kg}$ of calcium $\left(\mathrm{CaCO}_{3}\right.$ p.a. $)$ and magnesium $\left(\mathrm{MgCO}_{3}\right.$ p.a.) carbonates in 4:1 proportion, for $\mathrm{Ca}$ and $\mathrm{Mg}$ supply (Ribeiro; Guimarães; Alvarez, 1999).

After 45 days of cultivation, the legume Crotalaria juncea was starting to flower, thus the shoots and roots of all legumes were removed. The roots were separated from the aerial part at the base of the stem, sieved and washed under running water to remove soil particles. Then, soil samples were taken from each experimental unit for chemical characterization, without repetition (Table 2), following the procedures described by Teixeira et al. (2017).

Coffee seedlings (Coffea arabica) from the cultivar MGS Paraíso 2 were grown in plastic bags for 60 days, then the uniform seedlings were transplanted into the experimental pots. Each seedling was transplanted to a separate pot by cutting out the bottom of the bag. Afterwards, the soils were fertilized with nutrient solution, except for $\mathrm{P}$, as indicated by Novais et al. (1991). For both soils, the doses of nutrients consisted of $0.1,0.04,0.00081,0.00366,0.00015,0.004$, 0.00133 , and $0.00156 \mathrm{~kg} \mathrm{~m}^{-3}$ soil of $\mathrm{N}, \mathrm{S}, \mathrm{B}, \mathrm{Mn}, \mathrm{Mo}, \mathrm{Zn}, \mathrm{Cu}$, and $\mathrm{Fe}$, respectively, and the following sources were used: $\mathrm{NH}_{4} \mathrm{NO}_{3}, \mathrm{~K}_{2} \mathrm{SO}_{4}, \mathrm{H}_{3} \mathrm{BO}_{3}, \mathrm{MnCl}_{2} \cdot 4 \mathrm{H}_{2} \mathrm{O}, \mathrm{NaMoO}_{4} \cdot 2 \mathrm{H}_{2} \mathrm{O}, \mathrm{ZnCl}_{2}$, $\mathrm{CuCl}$, and $\mathrm{FeCl}_{3} \cdot 6 \mathrm{H}_{2} \mathrm{O}$, respectively. Besides, in the LVwf soil, $0.3 \mathrm{~kg} \mathrm{~m}^{-3}$ of $\mathrm{K}$ was applied, using $\mathrm{KCl}$ as the source, as well as $0.00204 \mathrm{~kg}$ of calcium $\left(\mathrm{CaCO}_{3}\right.$ p.a. $)$ and magnesium $\left(\mathrm{MgCO}_{3}\right.$ p.a.) carbonates in 4:1 proportion, for $\mathrm{Ca}$ and $\mathrm{Mg}$ supply (Ribeiro; Guimarães; Alvarez, 1999).

\subsection{Coffee agronomic and nutritional evaluations}

After 120-day coffee cultivation, seedling growth and nutritional status were estimated. The following growth parameters were determined: plant height $(\mathrm{PH})$, stem diameter
(SD) at $5 \mathrm{~cm}$ height from ground level, shoot dry matter (SDM), root dry matter (RDM), total dry matter (TDM), and Dickson's quality index (DQI). The PH was measured using a ruler graduated in centimeters $(\mathrm{cm})$, while SD was measured with a digital caliper with a precision of $0.01 \mathrm{~mm}$. Both SDM and TDM were quantified after collecting plants and separating roots from shoots by cutting them out at the base of stems. After cutting the shoots, the roots were collected, washed in running water over a $0.0005 \mathrm{~m}$ sieve. Both shoot and root were packed separately in paper bags, dried in an oven at $65^{\circ} \mathrm{C}$ for $72 \mathrm{~h}$, and weighed on an analytical scale.

The DQI was calculated using the formula proposed by Dickson, Leaf and Hosner (1960), as follows:

$$
\mathrm{DQI}=\frac{\mathrm{TDM}}{(\mathrm{PH} / \mathrm{SD})+(\mathrm{SDM} / \mathrm{RDM})}
$$

Macronutrient contents (N, P, K, Ca, Mg, and S) were determined by processing shoots and roots in a Willey type mill. Besides, nitro-perchloric digestion (Malavolta; Vitti; Oliveira, 1997) was performed to quantify levels of P, K, Ca, $\mathrm{Mg}$, and $\mathrm{S}$, which were determined by ICP-OES (inductively coupled plasma optical emission spectrometry). The content of $\mathrm{N}$ was quantified by sulfuric digestion and Kjeldahl distillation (Tedesco; Gianello, 1979).

Nutrient-use efficiency indexes were calculated using dry matter weight and $\mathrm{P}$ content of each plant part (Amaral et al., 2011), as follows:

$$
\mathrm{NUE}=\frac{(\mathrm{TDM})^{2}}{\mathrm{P} \text { content in the entire plant }}, \mathrm{in}_{\mathrm{kg}^{2} \mathrm{~kg}^{-1}}
$$

Nutrient-use efficiency for shoot production (NUESP):

\begin{tabular}{|c|c|c|c|c|c|c|c|}
\hline \multirow{2}{*}{ Legume species } & $\mathrm{pH}$ & $\mathrm{Ca}^{2+}$ & $\mathrm{Mg}^{2+}$ & K-available * & P-available * & $\mathrm{Al}^{3+}$ & $\mathrm{H}+\mathrm{Al}$ \\
\hline & $\mathrm{H}_{2} \mathrm{O}$ & \multicolumn{2}{|c|}{$\mathrm{cmol}_{\mathrm{c}} \mathrm{kg}^{-1}$} & \multicolumn{2}{|c|}{--------- kg m-3 -------- } & \multicolumn{2}{|c|}{$\mathrm{cmol}_{\mathrm{c}} \mathrm{kg}^{-1}$} \\
\hline \multicolumn{8}{|c|}{ LVwf } \\
\hline Crotalaria juncea & 5.63 & 0.83 & 0.53 & 0.0186 & 0.0003 & 0.00 & 3.54 \\
\hline Cajanus cajan & 5.16 & 0.70 & 0.40 & 0.0216 & 0.0003 & 0.00 & 3.69 \\
\hline Canavalia ensiformis & 5.75 & 0.76 & 0.53 & 0.0097 & 0.0015 & 0.00 & 3.98 \\
\hline Mucuna aterrima & 5.88 & 0.95 & 0.63 & 0.0255 & 0.0002 & 0.00 & 3.98 \\
\hline \multicolumn{8}{|c|}{ RLm } \\
\hline Crotalaria juncea & 6.32 & 13.04 & 4.42 & 0.0898 & 0.8327 & 0.00 & 6.49 \\
\hline Cajanus cajan & 6.11 & 14.14 & 5.30 & 0.1043 & 0.8521 & 0.00 & 6.63 \\
\hline Canavalia ensiformis & 6.17 & 14.02 & 4.54 & 0.0898 & 0.7615 & 0.00 & 6.78 \\
\hline Mucuna aterrima & 6.32 & 14.76 & 4.51 & 0.0898 & 0.8424 & 0.00 & 6.63 \\
\hline
\end{tabular}

Table 2: Chemical characterization of the soils after 45-day cultivation with legumes.

* Determined by the Mehlich ${ }^{-1}$ extractor.

LVwf: Typical Acriferic Red Oxisol (in Portuguese: Latossolo Vermelho Acriférrico típico); RLm: Typical Chernossolic Litholytic Entisol (in Portuguese: Neossolo Litólico Chernossólico típico). 
$\mathrm{NUESP}=\frac{(\mathrm{SDM})^{2}}{\mathrm{P} \text { content in the entire plant }}$, in $\mathrm{kg}^{2} \mathrm{~kg}^{-1}$

Nutrient-use efficiency for root production (NUERP):

NUERP $=\frac{(\mathrm{RDM})^{2}}{\mathrm{P} \text { content in the entire plant }}$, in $\mathrm{kg}^{2} \mathrm{~kg}^{-1}$

Using the $\mathrm{P}$ contents, $\mathrm{P}$ translocation index (PTI) was calculated (Abichequer; Bohnen, 1998), as follows:

PTI $=\frac{\mathrm{P} \text { content in the plant shoot }}{\mathrm{P} \text { content in the entire plant }} \times 100$

\subsection{Statistical analysis}

The data were submitted to analysis of variance (ANOVA) by the F-test $(\mathrm{p}<0.05)$ and, if significant, the averages were compared by the Tukey's test $(p<0.05)$. All statistical procedures were conducted with the aid of the SISVAR software (Ferreira, 2014).

\section{RESULTS}

\subsection{Coffee plant growth}

After 120-day cultivation, there was no significant interaction $(p>0.05)$ between soil types and legume species for coffee seedling growth parameters (Table 3 ). When cultivated in RLm, coffee seedlings showed higher values of
$\mathrm{PH}, \mathrm{SD}, \mathrm{SDM}$, TDM, and DQI, with increments of $13.05 \%$ in $\mathrm{PH}, 4.86 \%$ in SD, $46.98 \%$ in SDM, 17 , and $41.80 \%$ in TDM compared to seedlings grown in LVwf.

\subsection{Coffee shoot and root contents of macronutrients}

There was an interaction $(\mathrm{p}<0.05)$ between soil types and legume species only for coffee shoot $\mathrm{K}$ contents (Table 4). However, no interaction was observed for the other macronutrients ( $\mathrm{N}, \mathrm{P}, \mathrm{Ca}, \mathrm{Mg}$, and $\mathrm{S})$. By analyzing the effect of each factor individually, we observed that coffee seedlings grown in RLm had superior shoot contents of $\mathrm{N}, \mathrm{P}, \mathrm{Ca}, \mathrm{Mg}$, and $\mathrm{S}$ compared to those grown in LVwf.

The interaction between legume species and soil types was broken downinto coffee seedling shoot $\mathrm{K}$ contents and root $\mathrm{P}, \mathrm{Mg}$, and $\mathrm{K}$ contents separately (Table 5). In terms of pre-cultivation with legumes, except for root $\mathrm{K}$ content, there was no difference among treatments when coffee seedlings were cultivated in LVwf. But when grown in RLm, the seedlings in treatments without pre-cultivated plants and after Crotalaria juncea cultivation showed the lowest values of shoot $\mathrm{K}$ content and root $\mathrm{P}, \mathrm{Mg}$, and $\mathrm{K}$ contents, and after Mucuna aterrima cultivation for root $\mathrm{P}, \mathrm{Mg}$, and $\mathrm{K}$ contents.

\subsection{Nutritional efficiency of phosphorus in coffee seedlings}

There was no significant interaction between legume species and soil types for nutrient use efficiency (NUE), nutrient use efficiency for shoot production (NUESP), and nutrient use

Table 3: Coffee seedling growth parameters during 120-day cultivation, after cultivation with legumes in soils with contrasting $\mathrm{P}$ contents.

\begin{tabular}{|c|c|c|c|c|c|c|}
\hline \multirow{2}{*}{ Treatment } & $\mathrm{PH}$ & SD & SDM & $\mathrm{RDM}$ & TDM & \multirow{2}{*}{ DQI } \\
\hline & \multicolumn{2}{|c|}{------- $\mathrm{m}$------- } & \multicolumn{3}{|c|}{ 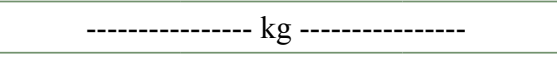 } & \\
\hline \multicolumn{7}{|c|}{ Legume species (L) } \\
\hline Crotalaria juncea & $0.3811 \mathrm{a}$ & $0.00607 \mathrm{a}$ & $0.0112 \mathrm{a}$ & $0.0023 a$ & $0.0135 \mathrm{a}$ & $1.21 \mathrm{a}$ \\
\hline Cajanus cajan & $0.3850 \mathrm{a}$ & $0.00554 \mathrm{ab}$ & $0.0098 \mathrm{ab}$ & $0.0019 \mathrm{a}$ & $0.0116 \mathrm{ab}$ & $0.94 \mathrm{ab}$ \\
\hline Canavalia ensiformis & $0.3753 \mathrm{a}$ & $0.00598 \mathrm{a}$ & $0.0095 \mathrm{ab}$ & $0.0019 \mathrm{a}$ & $0.0114 \mathrm{ab}$ & $1.01 \mathrm{ab}$ \\
\hline Mucuna aterrima & $0.3862 \mathrm{a}$ & $0.00580 \mathrm{a}$ & $0.0101 \mathrm{ab}$ & $0.0019 \mathrm{a}$ & $0.0119 \mathrm{ab}$ & $0.93 \mathrm{ab}$ \\
\hline Without pre-cultivated plant & $0.3863 \mathrm{a}$ & $0.00508 \mathrm{~b}$ & $0.0085 b$ & $0.0016 \mathrm{a}$ & $0.0101 \mathrm{~b}$ & $0.79 b$ \\
\hline \multicolumn{7}{|c|}{ Soil type(S) } \\
\hline LVwf & $0.3593 b$ & $0.0056 \mathrm{~b}$ & $0.0079 b$ & $0.0018 \mathrm{a}$ & $0.0097 \mathrm{~b}$ & $0.88 \mathrm{~b}$ \\
\hline RLm & $0.4062 \mathrm{a}$ & $0.0058 \mathrm{a}$ & $0.0117 \mathrm{a}$ & $0.0021 \mathrm{a}$ & $0.0137 \mathrm{a}$ & $1.07 \mathrm{a}$ \\
\hline $\mathrm{L} * \mathrm{~S}$ & ns & Ns & ns & ns & ns & ns \\
\hline C.V. $(\%)$ & 5.91 & 8.77 & 17.36 & 39.68 & 19.10 & 32.83 \\
\hline Overall average & 0.3828 & 0.0057 & 0.0098 & 0.0019 & 0.0117 & 0.0009 \\
\hline
\end{tabular}

PH: plant height, SD: stem diameter, SDM: shoot dry matter, RDM: root dry matter, TDM: total dry matter, DQI: Dickson's quality index. LVwf: Typical Acriferic Red Oxisol; RLm: Typical Chernossolic Litholytic Entisol; L*S: legume species X soil type interaction; C.V.: coefficient of variation; ns: non-significant by the ANOVA F-test; Different letters in the column differ significantly by the Tukey's test at $5 \%$ probability. 
efficiency for root production (NUERP) for coffee seedlings (Table 6);yet, there was an interaction for $\mathrm{P}$ translocation index (PTI). When considering the studied factors, the two soil types (RLm and LVwf) showed no significant difference for NUE, EUPA, and NUERP. Moreover, pre-cultivation with Canavalia ensiformis provided the lowest NUESP and shoot production per $\mathrm{P}$ unit, with no significant difference to NUERP.

The interaction between the effects of legume species and soil types was broken down for coffee seedling PTI. For seedlings grown in LVwf, all legume species used in precultivation showed no differences. But when grown in RLm, pre-cultivation with Mucuna aterrima provided the highest PTI values, while pre-cultivation with Crotalaria juncea had the lowest ones. Among the legume species used in pre- cultivation, only Mucuna aterrima exhibited different PTI values for coffee seedlings grown in both soils, with seedlings cultivated in RLm showing the highest ones (Table 7).

\section{DISCUSSION}

\subsection{Coffee plant growth}

Our findings revealed that pre-cultivation with Crotalaria juncea provided increases in SD, SDM, TDM, and DQI for coffee seedlings, with increments of $20 \%, 33 \%, 34 \%$, and $52 \%$, respectively, compared to the control (without pre-cultivated plant). DQI is taken as a seedling quality indicator since it considers the biomass balance distribution of seedlings (Fonseca et al., 2002). The higher the DQI, the better the plant biomass

Table 4: Macronutrients concentration in the shoots and roots of coffee seedlings grown for 120 days, after cultivation with legumes, in soils with contrasting $\mathrm{P}$ contents.

\begin{tabular}{|c|c|c|c|c|c|c|}
\hline Treatment & $\mathrm{N}$ & $\mathrm{P}$ & $\mathrm{Ca}$ & $\mathrm{Mg}$ & $\mathrm{K}$ & $\mathrm{S}$ \\
\hline \multicolumn{7}{|c|}{ Shoot content $(\mathrm{kg})$} \\
\hline \multicolumn{7}{|c|}{ Legume species (L) } \\
\hline Crotalaria juncea & $0.0283 \mathrm{a}$ & $0.0009 \mathrm{ab}$ & $0.0065 \mathrm{ab}$ & $0.0026 \mathrm{ab}$ & - & $0.0016 \mathrm{ab}$ \\
\hline Cajanus cajan & $0.0291 \mathrm{a}$ & $0.0011 \mathrm{ab}$ & $0.0078 \mathrm{ab}$ & $0.0030 \mathrm{a}$ & - & $0.0019 \mathrm{ab}$ \\
\hline Canavalia ensiformis & $0.0296 \mathrm{a}$ & $0.0012 \mathrm{a}$ & $0.0081 \mathrm{a}$ & $0.0032 \mathrm{a}$ & - & $0.0019 \mathrm{a}$ \\
\hline Mucuna aterrima & $0.0283 \mathrm{a}$ & $0.0011 \mathrm{ab}$ & $0.0073 \mathrm{ab}$ & $0.0029 \mathrm{ab}$ & - & $0.0018 \mathrm{ab}$ \\
\hline Without pre-cultivated plant & $0.0303 a$ & $0.0008 \mathrm{~b}$ & $0.0059 \mathrm{~b}$ & $0.0022 b$ & - & $0.0014 b$ \\
\hline \multicolumn{7}{|c|}{ Soil type (S) } \\
\hline LVwf & $0.0278 b$ & $0.0009 b$ & $0.0062 b$ & $0.0025 b$ & - & $0.0015 b$ \\
\hline RLm & $0.0305 \mathrm{a}$ & $0.0011 \mathrm{a}$ & $0.0080 \mathrm{a}$ & $0.0030 \mathrm{a}$ & - & $0.0018 \mathrm{a}$ \\
\hline$L^{*} \mathrm{~S}$ & ns & ns & ns & ns & $* *$ & ns \\
\hline C.V. $(\%)$ & 7.94 & 27.34 & 24.60 & 25.30 & 44.47 & 23.20 \\
\hline Overall average & 0.0291 & 0.0010 & 0.0071 & 0.0028 & 0.0076 & 0.0017 \\
\hline Treatments & $\mathrm{N}$ & $\mathrm{P}$ & $\mathrm{Ca}$ & $\mathrm{Mg}$ & $\mathrm{K}$ & $\mathrm{S}$ \\
\hline \multicolumn{7}{|c|}{ Root content $(\mathrm{kg})$} \\
\hline \multicolumn{7}{|c|}{ Legume species $(\mathrm{L})$} \\
\hline Crotalaria juncea & nd & - & $0.0078 \mathrm{a}$ & - & - & $0.0034 \mathrm{a}$ \\
\hline Cajanus cajan & nd & - & $0.0078 \mathrm{a}$ & - & - & $0.0034 \mathrm{a}$ \\
\hline Canavalia ensiformis & nd & - & $0.0076 \mathrm{a}$ & - & - & $0.0033 \mathrm{a}$ \\
\hline Mucuna aterrima & nd & - & $0.0076 \mathrm{a}$ & - & - & $0.0036 \mathrm{a}$ \\
\hline Without pre-cultivated plant & nd & - & $0.0077 \mathrm{a}$ & - & - & $0.0034 \mathrm{a}$ \\
\hline \multicolumn{7}{|c|}{ Soil type(S) } \\
\hline LVwf & nd & - & $0.0058 \mathrm{~b}$ & - & - & $0.0034 \mathrm{a}$ \\
\hline RLm & nd & - & $0.0096 \mathrm{a}$ & - & - & $0.0035 \mathrm{a}$ \\
\hline $\mathrm{L}^{*} \mathrm{~S}$ & nd & $* *$ & ns & $*$ & $* *$ & ns \\
\hline C.V. $(\%)$ & nd & 13.61 & 11.66 & 10.88 & 16.79 & 8.57 \\
\hline Overall average & nd & 0.0012 & 0.0077 & 0.0092 & 0.0112 & 0.0034 \\
\hline
\end{tabular}

LVwf: Typical Acriferic Red Oxisol; RLm: Typical Chernossolic Litholytic Entisol; LS: legume species X soil type interaction; C.V.: coefficient of variation; ns: non-significant, nd: non-determined, ${ }^{* *}$ and ${ }^{*}$ significant at $1 \%$ and $5 \%$ probability, respectively, by the ANOVA F-test; Different letters in the column differ significantly by the Tukey's test at $5 \%$ probability. 
distribution. The other legumes used in pre-cultivation showed similar results for the studied parameters, except for Canavalia ensiformis and Mucuna aterrima, which led to increases in SD. Our results also showed no differences for PH and RDM.

The highest values of coffee growth parameters in RLm can be justified by its higher available P contents. The Law of the Minimum says that plant growth is limited by the low availability of an essential element in the soil, failing to meet plant demands, even if the other nutrients are available in balanced amounts (Lepsch, 2016). When growing coffee seedlings in soils with high and low levels of $\mathrm{P}$, Neto et al. (2016) also observed a reduction in the production of plant biomass from plants when cultivated in soil with low $\mathrm{P}$ content.

Despite the lack of $\mathrm{P}$ availability to the growth of coffee seedlings in LVwf, pre-cultivation with Crotalaria juncea showed to be a promising alternative to supply $\mathrm{P}$ contents to the following crop. Therefore, this legume species stood out for precultivation, providing increases in coffee growth parameters.

Table 5: Breakdown analysis of the interaction between legume species ( $L$ ) and soil types $(\mathrm{S})$ for coffee seedling shoot $\mathrm{K}$ content and root $\mathrm{P}, \mathrm{Mg}$, and $\mathrm{K}$ contents after 120-day cultivation.

\begin{tabular}{|c|c|c|c|c|c|}
\hline $\mathrm{L} \times \mathrm{S}$ & Crotalaria juncea & Cajanus cajan & Canavalia ensiformis & Mucuna aterrima & Without pre-cultivated plant \\
\hline \multicolumn{6}{|c|}{ Shoot K content (kg) } \\
\hline LVwf & $0.0068 \mathrm{aA}$ & $5.44 \mathrm{bA}$ & $0.0064 \mathrm{bA}$ & $0.0052 \mathrm{bA}$ & $0.0049 \mathrm{aA}$ \\
\hline RLm & $0.0049 \mathrm{aB}$ & $12.10 \mathrm{aA}$ & $0.0107 \mathrm{aA}$ & $0.0126 \mathrm{aA}$ & $0.0072 \mathrm{aAB}$ \\
\hline \multicolumn{6}{|c|}{ Root $\mathrm{P}$ content $(\mathrm{kg})$} \\
\hline LVwf & $0.0011 \mathrm{aA}$ & $0.0009 \mathrm{bA}$ & $0.0009 \mathrm{bA}$ & $0.0010 \mathrm{bA}$ & $0.0010 \mathrm{aA}$ \\
\hline RLm & $0.0012 \mathrm{aB}$ & $0.0017 \mathrm{aA}$ & $0.0016 \mathrm{aA}$ & $0.0013 \mathrm{aB}$ & $0.0011 \mathrm{aB}$ \\
\hline \multicolumn{6}{|c|}{ Root Mg content (kg) } \\
\hline LVwf & $0.0094 \mathrm{aA}$ & $0.0087 \mathrm{bA}$ & $0.0085 \mathrm{bA}$ & $0.0087 \mathrm{aA}$ & $0.0089 \mathrm{aA}$ \\
\hline RLm & $0.0092 \mathrm{aAB}$ & $0.0105 \mathrm{aA}$ & $0.0103 \mathrm{aA}$ & $0.0087 \mathrm{aB}$ & $0.0095 \mathrm{aAB}$ \\
\hline \multicolumn{6}{|c|}{ Root $\mathrm{K}$ content $(\mathrm{kg})$} \\
\hline LVwf & $0.0092 \mathrm{aB}$ & $0.0110 \mathrm{bAB}$ & $0.0085 \mathrm{bB}$ & $0.0097 \mathrm{aB}$ & $0.0129 \mathrm{aA}$ \\
\hline RLm & $0.0103 \mathrm{aB}$ & $0.0152 \mathrm{aA}$ & $0.0129 \mathrm{aAB}$ & $0.0112 \mathrm{aB}$ & $0.0113 \mathrm{aB}$ \\
\hline
\end{tabular}

LVwf: Typical Acriferic Red Oxisol; RLm: Typical Chernossolic Litholytic Entisol; Different lower-case letters in the column and different upper-case letters in the row differ significantly by the Tukey's test at $5 \%$ probability.

Table 6: Nutrient use efficiency (NUE), nutrient use efficiency for shoot production (NUESP), nutrient use efficiency for root production (NUERP), and $\mathrm{P}$ translocation index (PTI) in coffee seedlings after 120-day cultivation.

\begin{tabular}{|c|c|c|c|c|}
\hline \multirow{2}{*}{ Treatments } & NUE & NUESP & NUERP & PTI \\
\hline & \multicolumn{3}{|c|}{--------- kg² $\mathrm{kg}^{-1}$--------- } & $\%$ \\
\hline \multicolumn{5}{|c|}{ Legume species(L) } \\
\hline Crotalaria juncea & $15.45 \mathrm{a}$ & $10.64 \mathrm{a}$ & $0.47 \mathrm{a}$ & - \\
\hline Cajanus cajan & $10.72 \mathrm{ab}$ & $7.61 \mathrm{ab}$ & $0.29 \mathrm{a}$ & - \\
\hline Canavalia ensiformis & $9.77 \mathrm{~b}$ & $6.70 \mathrm{~b}$ & $0.31 \mathrm{a}$ & - \\
\hline Mucuna aterrima & $12.17 \mathrm{ab}$ & $8.54 \mathrm{ab}$ & $0.38 \mathrm{a}$ & - \\
\hline Without pre-cultivated plant & $12.46 \mathrm{ab}$ & $8.82 \mathrm{ab}$ & $0.34 \mathrm{a}$ & - \\
\hline \multicolumn{5}{|c|}{ Soil type (S) } \\
\hline LVwf & $11.81 \mathrm{a}$ & $7.96 \mathrm{a}$ & $0.40 \mathrm{a}$ & - \\
\hline RLm & $12.42 \mathrm{a}$ & $8.96 \mathrm{a}$ & $0.32 \mathrm{a}$ & - \\
\hline $\mathrm{L} * \mathrm{~S}$ & ns & $\mathrm{ns}$ & $\mathrm{ns}$ & $*$ \\
\hline C.V. $(\%)$ & 35.00 & 34.53 & 64.52 & 8.82 \\
\hline Overall average & 12.11 & 8.46 & 0.36 & 80.40 \\
\hline
\end{tabular}

LVwf: Typical Acriferic Red Oxisol; RLm: Typical Chernossolic Litholytic Entisol; L*S: legume species X soil type interaction; C.V.: coefficient of variation; ns: non-significant, and * and * significant at $1 \%$ and $5 \%$ probability; Different letters in the column differ significantly by the Tukey's test at $5 \%$ probability. 
Table 7: Breakdown analysis of the interaction between legume species (L) and soil types (S) for PTI of coffee seedlings after 120-day cultivation.

\begin{tabular}{cccccc}
\hline Lx S & Crotalaria juncea & Cajanus cajan & Canavalia ensiformis & Mucuna aterrima & Without pre-cultivated plant \\
\hline LVwf & $78.82 \mathrm{aA}$ & $82.06 \mathrm{aA}$ & $80.31 \mathrm{aA}$ & $73.86 \mathrm{bA}$ & $78.02 \mathrm{aA}$ \\
RLm & $77.70 \mathrm{aB}$ & $80.82 \mathrm{aAB}$ & $83.14 \mathrm{aAB}$ & $89.48 \mathrm{aA}$ & $79.76 \mathrm{aAB}$ \\
\hline
\end{tabular}

LVwf: Typical Acriferic Red Oxisol; RLm: Typical Chernossolic Litholytic Entisol; Different lower-case letters in the column and different upper-case letters in the row differ significantly by the Tukey's test at $5 \%$ probability.

The cycling of $\mathrm{P}$ and other nutrients is important for coffee nutrition (Cardoso et al., 2018) due to reductions in costs and dependence on industrial inputs for coffee growing (Vilela et al., 2011). Green manuring is a technique that has shown promising results for coffee plants (Paulo et al., 2006; Araújo et al., 2013; Vilela et al., 2011; Cardoso et al., 2018; Jaeggi et al., 2019; Franco Junior et al., 2019), either in pre-cultivation or intercropped in-between rows of already-established crops.

\subsection{Macronutrients in coffee shoots and roots}

Our results show that coffee seedlings grown after Canavalia ensiformis had higher shoot levels of $\mathrm{P}, \mathrm{Ca}, \mathrm{Mg}$, and $\mathrm{S}$ compared to the control. Unlike, no differences were observed for Namong legume species. Thus, pre-cultivation with Canavalia ensiformis promote benefits to posterior coffee cultivation. Legumes can mobilize nutrients and make them available to successor crops. Therefore, green manuring in coffee plantations can reduce the requirements for fertilizer application over time.

Our findings also revealed a significant interaction between soil types and legume species for $\mathrm{P}, \mathrm{Mg}$, and $\mathrm{K}$ levels. Oppositely, the interaction between $\mathrm{Ca}$ and $\mathrm{S}$ levels in coffee roots (Table 4) had no significant results. The content of $\mathrm{Ca}$ was higher in roots of seedlings grown in RLm, while those of S showed no differences between soil types. Regarding the effect of pre-cultivation with legume species, the contents of $\mathrm{Ca}$ and $\mathrm{S}$ in coffee roots exhibited no significant differences.

\subsection{Nutritional efficiency of phosphorus in coffee seedlings}

According to Amaral et al. (2011), the term "nutritional efficiency" has been used to characterize plant ability to absorb and use nutrients, which is related to its efficiency of absorption, translocation, and use of nutrients. In most studies on nutritional efficiency, P-use efficiency has been increasingly evidenced (Amaral et al., 2011). However, in our study, an increase in $\mathrm{P}$ availability did not allow us to identify differences between coffee seedlings grown in soils with different $P$ availability. This might have occurred because only a single species and cultivar was assessed. Different plant species differ in their responses to soil nutrient availability, as they show differences in their absorption capacity and use efficiency (Tomaz et al., 2008).
Pre-cultivation with legumes, in turn, enabled us to detect significant differences between coffee seedlings, especially for those grown after Crotalaria juncea. Phosphorus mobilization by this legume species during its cultivation may have increased P-use efficiency and coffee shoot and root productions per $\mathrm{P}$ unit. Franco Junior et al. (2019) observed that the consortium with Crotalaria juncea showed positive responses to the coffee initial development in the field and better conditions of soil humidity and temperature. Crotalaria juncea can still bring other benefits to coffee, as observed by Supriyad et al. (2019), in which Crotalaria juncea stimulated the increase in abundance of predators and parasitoid insects in the coffee ecosystem.

Translocation refers to the movement or transfer of an ion from its absorption site in roots to any other point in the plant, whether inside or outside the root system (Malavolta; Vitti; Oliveira, 1997). Phosphorus translocation index (PTI) is expressed as the percentage of $\mathrm{P}$ transferred to plant shoot in relation to the total amount absorbed (Abichequer; Bohnen, 1998). In this sense, the higher the PTI, the greater the translocated amount from plant roots to shoot (Silva; Vitti; Trevizam, 2007). In our study, there was a high P translocation from coffee seedling roots to shoot, even when grown in the low-P availability soil. Contrary to what occurs in soil, $\mathrm{P}$ has high mobility within plant tissues, easily translocating from roots to shoot (Novais; Smyth, 1999).

\section{CONCLUSIONS}

Pre-cultivation with legume species increases coffee seedling growth, mainly with Crotalaria juncea plants;

Coffee seedlings grown after Canavalia ensiformis cultivation have higher shoot levels of $\mathrm{P}, \mathrm{Ca}, \mathrm{Mg}$, and $\mathrm{S}$;

Pre-cultivation with Crotalaria juncea can be a promising alternative to supplement phosphorus to successor crops in low-P availability soils.

\section{ACKNOWLEDGMENTS}

To the Coordination for Improvement of Higher Education Personnel (Coordenação de Aperfeiçoamento de Pessoal de Nivel Superior-CAPES) and the National Research Council (Conselho Nacional de Pesquisa-CNPq) for funding and granting scholarships. This study was financed in part by the CAPES, under the finance code 001. 


\section{REFERENCES}

ABICHEQUER, A. D.; BOHNEN, H. Eficiência de absorção, translocação e utilização de fósforo por variedades de trigo. Revista Brasileira de Ciência do Solo, 22(1):2126, 1998.

AMABILE, R. F.; CARVALHO, A. M. Histórico da adubação verde. In: CARVALHO, A. M.; AMABILE, R. F. (eds.). Cerrado: Adubação verde. Planaltina, DF: EMBRAPA Cerrados, p. 23-40, 2006.

AMARAL, J. F. T. D. et al. Eficiência de utilização de nutrientes por cultivares de cafeeiro. Ciência Rural, 41(4):621-629, 2011.

ARAUJO, J. B. S. et al. Nitrogen fertilization of coffee: Organic compost and Crotalaria juncea L. Revista Ceres, 60(6):842-851, 2013.

CARDOSO, R. G. S. et al. Intercropping period between species of green manures and organically-fertilized coffee plantation. Coffee Science, 13(1):23-32, 2018.

CASALI, C. A. et al. Mineralização das formas de fósforo do tecido de plantas de cobertura. Informações Agronômicas, 135:21-24, 2011.

DICKSON, A.; LEAF, A. L.; HOSNER, J. F. Quality appraisal of white spruce and white pine seedling stock in nurseries. Forest Chronicle, 36:10-13, 1960.

ELSER, J.; BENNETT, E. Phosphorus cycle: a broken biogeochemical cycle. Nature, 478:29-31, 2011.

FERREIRA, D. F. Sisvar: A guide for its bootstrap procedures in multiple comparisons. Ciência e Agrotecnologia, 38(2):109-112, 2014.

FONSECA, E. P. et al. Padrão de qualidade de mudas de Trema micrantha (L.) Blume, produzidas sob diferentes períodos de sombreamento. Revista Árvore, 26(4):515$523,2002$.

FRANCO JUNIOR, K. S. et al. Effect of intercropping in shading with crotalaria on the initial development of coffee tree. Coffee Science, 14(4):544-549, 2019.

JAEGGI, M. E. P. C. et al. Path analysis of vegetative characteristics in conilon coffee production consortiated with green fertilizers in tropical climate. Journal of Experimental Agriculture International, 40(2):1-11, 2019.

KOPPEN, W. Climatologia com um estudio de los climas de la tierra. México: Fondo de Cultura Económica, 1948. 478p.
LEMOS, V. T. et al. Ácido cítrico e fósforo no desenvolvimento e estado nutricional de mudas de café. Coffee Science, 10(3):298-308, 2015.

LEPSCH, I. F. Formação e conservação dos solos. 2. ed. São Paulo: Oficina de textos, 2010. 216p.

LORENZON, A. S.; DIAS, H. C. T.; LEITE, H. G. Precipitação efetiva e interceptação da chuva em um fragmento florestal com diferentes estágios de regeneração. Revista Árvore, 37(4):619-627, 2013.

MALAVOLTA, E.; VITTI, G. C.; OLIVEIRA, S. A. Avaliação do estado nutricional das plantas: Princípios e aplicações. Piracicaba: POTAFOS, 1997. 319p.

MASCARENHAS, H. A. A.; WUTKE, E. B. Adubação, nutrição e fatores climáticos limitantes ao desenvolvimento dos adubos verdes. In: LIMA FILHO, O. F. et al. (eds.) Adubação verde e plantas de cobertura no Brasil: Fundamentos e prática. Brasília, DF: EMBRAPA Agropecuária Oeste, p. 189224, 2014.

NETO, A. P. et al. Analysis of phosphorus use efficiency traits in Coffea genotypes reveals Coffea arabica and Coffea canephora have contrasting phosphorus uptake and utilization efficiencies. Frontiers in plant science, 7:408, 2016

NOVAIS, R. D. et al. Métodos de pesquisa em fertilidade do solo. Brasília: EMBRAPA SEA, p. 189-253, 1991.

NOVAIS, R. F.; SMYTH, T. J. Fósforo em solo e planta sob condições tropicais. Raleigh: Universidade Federal de Viçosa - North Carolina State University, 1999. 399p.

NZIGUHEBA, G.; BÜNEMANN, E. K. Organic phosphorus dynamics in tropical agroecosystems. In: TURNER, B. L.; FROSSARD, E.; BALDWIN, D. $\mathrm{S}$. (Ed.). Organic phosphorus in the environment. Cambridge: CABI Publishing is a division of CAB International, p. 243-268, 2005.

PAULO, E. M. et al. Produtividade do cafeeiro Mundo Novo enxertado e submetido à adubação verde antes e após recepa da lavoura. Bragantia, 65(1):115-120, 2006.

RAIJ, B. V. Fertilidade do solo e adubação. Piracicaba, International Plant Nutrition Institute, 2011. 420p.

RIBEIRO, A. C.; GUIMARÃES, P. T. G.; ALVAREZ, V. V. H. Recomendações para o uso de corretivos e fertilizantes em Minas Gerais: $5^{\text {a }}$ aproximação. Comissão de Fertilidade do Solo do Estado de Minas Gerais, Viçosa: UFV, 1999. 359p. 
SANTINATO, F. et al. Doses of phosphorus associated with nitrogen on development of coffee seedlings. Coffee Science, 9(3):419-426, 2014.

SILVA, M. D. S.; VITTI, G. C.; TREVIZAM, A. R. Concentração de metais pesados em grãos de plantas cultivadas em solo com diferentes níveis de contaminação. Pesquisa Agropecuária Brasileira, 42(4):527-535, 2007.

SILVA, T. O. et al. Plantas de cobertura submetidas a diferentes fontes de fósforo em solos distintos. Semina: Ciências Agrárias, 32(4):1315-1326, 2011.

SILVA, I. M. et al. Respostas de genótipos de Coffea arabica à aplicação de fósforo em substrato com ácido cítrico. Revista de Ciências Agrárias, 62:1-7, 2019.

SOLTANGHEISI, A. et al. Changes in soil phosphorus lability promoted by phosphate sources and cover crops. Soil and Tillage Research, 179:20-28, 2018.

SUPRIYAD, R. W. et al. The effect of Crotalaria juncea plant in coffee ecosystem to the diversity and abundance of predators and parasitoids insects. IOP Conference Series: Earth and Environmental Science, 120:12-20, 2019.
TEDESCO, M. J.; GIANELLO, C. Conjunto modulado em vidro para destilação a vapor de amônia pelo método kjeldahl. Revista Brasileira de Ciência do Solo, 3:6163, 1979 .

TEIXEIRA, P. C. et al. Manual de métodos de análise de solos. 3.ed. rev. e ampl. Brasília, DF: Embrapa, 2017. 574p.

TOMAZ, M. A. et al. Diferenças genéticas na eficiência de absorção, na translocação e na utilização de K, Ca e $\mathrm{Mg}$ em mudas enxertadas de cafeeiro. Ciência Rural, 38(6):1540-1546, 2008.

TOMAZ, M. A. et al. Eficiência relacionada à absorção e utilização de nitrogênio, fósforo e enxofre, em plantas de cafeeiros enxertadas, cultivadas em vasos. Ciência e Agrotecnologia, 33(4):993-1001, 2009.

VILELA, E. F. et al. Crescimento inicial de cafeeiros e fertilidade do solo adubado com mucuna, amendoim forrageiro ou sulfato de amônio. Coffee Science, 6(1):2735,2011 .

VILELA JÚNIOR, D. et al. Initial growth of coffee seedling cultivars with different doses of nitrogen, phosphorus and potassium. Coffee Science, 12(4):552-561, 2017. 